\title{
New Chloride Leaching Process for Gold Extraction from Refractory Ores
}

From certain gold ores, known as refractory gold ores, the gold cannot be fully recovered by direct cyanide leaching. A major cause of this is the occurrence of much of the gold in such ores in highly disseminated form in sulfide, arsenide and sometimes antimonide minerals. Three methods have been developed for treatment of such refractory ores, each of which involves breaking down the sulfide and arsenide minerals by oxidation before cyanide extraction.

In one method, the sulfide and related minerals containing the gold are recovered by flotation, and roasted. The residues ( $\mathrm{S}$ - and As-free) are then leached with cyanide. In a second, recently developed process, the flotation concentrates are aerated in slurry form in a medium containing $S$ and As-oxidizing microorganisms before being leached with cyanide. In the third method, breakdown of the S- and As-minerals is achieved by oxidative treatment of the concentrate in an autoclave, followed by cyanide leaching.

Method 1 is gradually being abandoned because of environmental pollution problems, and new plants in the USA, South Africa, Australia and elsewhere tend to employ Method 2 or Method 3, which produce less severe problems of this type.

Over the past 10 years, however, there have been a number of publications which indicate that the direct oxidative chloride leaching of gold from refractory gold ores may prove to be an improvement on the methods now in use.

These new developments were reviewed by F K Letowski of the University of Witwatersrand in Johannesburg, at the International Conference on the Science and Technology of Gold at Hanau in Germany in June 1996 (1). They include:

\section{The use of less volatile 'chloride ion carriers'}

In the past, $\mathrm{HCl}$ has been used as the main chloride ion carrier in leaching solutions and $\mathrm{HNO}_{3}$ (or $\mathrm{Cl}_{2}$ ) as the oxidant. This has limited leaching temperatures because high partial pressures of $\mathrm{HCl}$ lead to loss of $\mathrm{Cl}^{-}$from the leaching solution. Partial substitution of $\mathrm{HCl}$ by $\mathrm{AlCl}_{3}$ or $\mathrm{ZnCl}_{2}$ has been found to decrease dramatically these partial pressures of $\mathrm{HCl}$, apparently as a result of the formation of $\mathrm{Al}$ and $\mathrm{Zn}$ chlorocomplexes. This has made the attainment of higher leaching temperatures and higher efficiencies possible. Decomposition of the refractory sulfides and arsenides occurs in the chloride leach solutions and their gold content made susceptible to cyanide leaching.

\section{The regeneration, in process, of nitric acid used as oxidant}

In the chloride leaching reaction, the nitric acid is reduced to $\mathrm{NO}$, the conversion of which back to $\mathrm{HNO}_{3}$ is costly by conventional methods. A 'leaching in froth' (L/F) process has been devised, however, which has been successfully applied on a laboratory scale for mineral graphite purification (2), zinc concentrate processing (3) and more recently for gold extraction from refractory gold ores.

In this process, oxygen and oxides of nitrogen are the flotation carriers and a chloride solution containing $\mathrm{HNO}_{3}$ is the reactive medium in which the hydrophobic particles of the ore are suspended. In operation, the outer walls of the froth cells are quickly saturated with oxygen and oxides of nitrogen, entering them from both their sides.

Instantaneous hydrolysis and disproportionation of $\mathrm{NO}_{2}$ through intermediate species regenerates a substantial fraction of the $\mathrm{HNO}_{3}$ fed to the system, which implies that the main oxidant in the process is oxygen.

Gold is recoverable by adsorption on carbon from the chloride leach solutions, which can be recycled.

The foundations appear to have been laid for a pilot plant evaluation of this process.

\section{WS Rapson}

\section{REFERENCES}

1 see D. Thompson, Gold Bull., 1996, 29, 105, no Proceedings are to be published

2 F.K. Letowski, 'Separation Processes: Heavy Metals, Ions and Minerals', The Minerals, Metals and Materials Society, Warrendale Pa, USA, 1995, p. 135

3 F.K. Letowski and D.P. Obeng, Proc. XIX Int. Mineral Processing Congr., Soc. Min. Metall. and Exploration Inc., Littleton, Colorado, 1995, 2, 251 